\title{
Appendicitis in a Pediatric Patient with Cystic Fibrosis: Difficulties in the Path to Diagnosis
}

\section{Kistik Fibrozisli Pediyatrik Hastada Apandisit: Tanıya Giden Yoldaki Zorluklar}

\author{
(1) Sabri Cansaran
}

Tokat State Hospital, Clinic of Pediatric Surgery, Tokat, Turkey

The production of non-fluid mucus and secretions in the lungs, gastrointestinal tract, pancreas, hepatobiliary and reproductive system is the most prominent feature of cystic fibrosis (CF) disease. In this study, it was aimed to present the diagnostic challenge in a pediatric appendicitis case with CF.

A 3.5-year-old girl with the complaint of abdominal pain that had been going on for four days was consulted with thesuspicion of acute abdomen. She had been diagnosed as CF with gastrointestinal involvement and had tenderness in the right lower quadrant with deep palpation on initial examination. After proper follow-up, because repeated ultrasonography revealed that the diameter of the appendix increased $(10 \mathrm{~mm})$ compared to the previous one, the response to compression decreased and there was minimal fluid in the pericecal area, it was decided to perform laparotomy. During the operation, there was a hard structure filling the whole appendix lumen and extending into the cecum. It was observed that the structure in the lumen was a hardened mucus plug causing partial obstruction.

Ultrasonography is a highly effective method in the diagnosis of appendicitis in younger children and can be easily repeated if necessary. Pediatric CF patients with refractory or unexplained abdominal symptoms deserve a higher index of suspicion. With the help of diagnostic tools, surgical intervention is both diagnostic and therapeutic, especially in patients who do not improve clinically.

Keywords: Cystic fibrosis, appendicitis, pediatric, mucus plug

Akciğerler, gastrointestinal yol, pankreas, hepatobiliyer ve reprodüktif sistemde akışkan olmayan mukus ve salgıların üretilmesi, kistik fibrozis (KF) hastalığının en belirgin özelliğidir. Bu çalışmada, KF’li bir pediyatrik apandisit olgusunda tanısal zorlukların sunulması amaçlanmıştır.

Dört gündür devam eden karın ağrısı şikayeti ile başvuran 3,5 yaşında kız hasta akut batın şüphesi ile konsülte edildi. Daha önce gastrointestinal tutulumlu KF tanısı almış hastanın ilk muayenesinde sağ alt kadranda derin palpasyonla hassasiyet mevcuttu. Uygun takip sonrası tekrarlanan ultrasonografide apendiksin çapının bir öncekine göre arttığı (10 mm), kompresyona yanıtın azaldığı ve periçekal bölgede minimal sıvı olduğunun görülmesi üzerine laparotomi yapılmasına karar verildi. Operasyonda, apendiksin tüm lümenini dolduran ve çekuma uzanım gösteren sert bir yapı mevcuttu. Lümen içindeki yapının, kısmi obstrüksiyona neden olan sertleşmiş bir mukus tıkacı olduğu görüldü.

Ultrasonografi, küçük çocuklardaki apandisit tanısında oldukça etkili bir yöntemdir ve gerekirse kolaylıkla tekrarlanabilir. İnatçı veya açıklanamayan abdominal semptomları olan pediatrik KF hastalarında daha şüpheci bir yaklaşım gereklidir. Tanı araçlarının da yardımıyla cerrahi müdahale, özellikle klinik olarak düzelmeyen hastalarda hem tanısal hem de tedavi edicidir.

Anahtar Kelimeler: Kistik fibrozis, apandisit, pediyatrik, mukus tıkacı 


\section{Introduction}

Since associated morbidity and mortality conditions generally develop due to pulmonary complications, cystic fibrosis (CF) is considered more as a lung disease. The pathology in CF is associated with abnormal chloride and bicarbonate transport caused by $\mathrm{CF}$ transmembrane regulator gene variants on chromosome 7 (1). The production of non-fluid mucus and secretions in the lungs, gastrointestinal tract, pancreas, hepatobiliary and reproductive system is the most prominent feature of CF disease. This condition causes luminal obstruction in these organs and the emergence of clinical signs related to the disease $(2,3)$.

Pancreatic dysfunction is a key expression for CF disease. In all patients with CF, secretin-induced biological substance release from the pancreatic ducts is reduced (4). The most common complication of CF related to the gastrointestinal tract is pancreatic insufficiency. Approximately $85 \%$ of patients experience pancreatic insufficiency at some time in their lives and it is present in most of them from birth (5).

Appendicitis is less common in patients with CF than in the general population. However, the diagnosis is difficult because it can mimic distal intestinal obstruction syndrome (DIOS) and other intestinal diseases associated with CF and cause atypical symptoms (6). In this study, it was aimed to present the diagnostic challenge in a pediatric appendicitis case with CF.

\section{Case Report}

A 3.5-year-old girl with the complaint of abdominal pain that had been going on for four days was consulted with the suspicion of acute abdomen. It was learned from her history that she was diagnosed as CF with gastrointestinal involvement and received $3 \times 30 \mathrm{mg}$ oral pancreatin (equivalent to 2,000 IU lipase) treatment. On abdominal examination, she had tenderness in the right lower quadrant with deep palpation. Her fever was within normal limits $\left(36.6^{\circ} \mathrm{C}\right)$. Except for severe constipation, no feature was observed on abdominal X-ray (Figure 1). In laboratory findings, there was $7,300 / \mathrm{dL}$ neutrophil count $(1,500-$ 8.000 ) within normal limits and $13,500 / \mathrm{dL}$ leukocytosis $(4,500-$ 12,000). Biochemistry parameters were normal and C-reactive protein value was negative. The abdomen ultrasound revealed that the appendicular transverse diameter increased to $9 \mathrm{~mm}$ and the response to compression decreased. Since abdominal physical examination findings did not significantly support acute appendicitis, follow-up decision with intravenous fluid resuscitation was made. On the second day, the patient's leukocytosis regressed $(8,500 / \mathrm{dL})$ and the C-reactive protein value was again negative. The patient who tolerated oral feeding on the same day did not have fever or vomiting. On the third day of follow-up, ultrasound was performed again due to recurrent abdominal pain and anorexia. Repeated ultrasound showed that the diameter of the appendix increased $(10 \mathrm{~mm})$ compared to the previous one, the response to compression decreased and there was minimal fluid in the pericecal area. Therefore, it was decided to perform laparotomy. During the operation, the appendix was distant with a very slight hyperemia, and there was a hard structure filling the whole lumen and extending into the cecum. After appendectomy, it was observed that the structure in the lumen was a hardened mucus plug causing partial obstruction (Figure 2). The patient was discharged on the second postoperative day with healing. Outpatient followup was uneventful and according to the pathology report, the specimen was compatible with acute appendicitis and the lumen was partially obliterated.

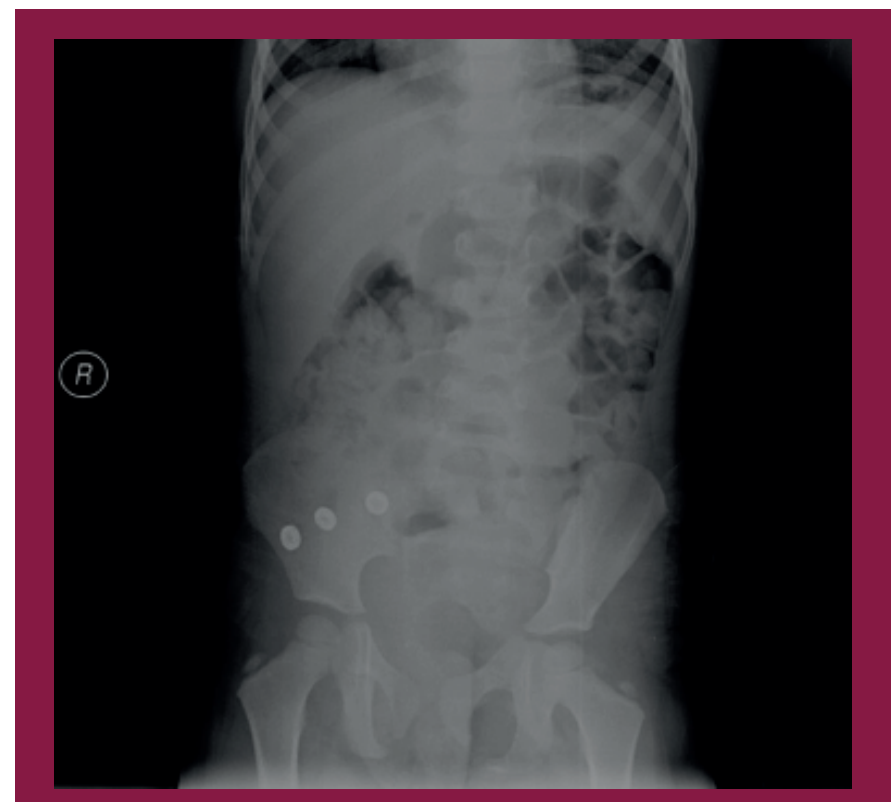

Figure 1. Fecal impaction in the abdominal X-ray of the patient at initial admission

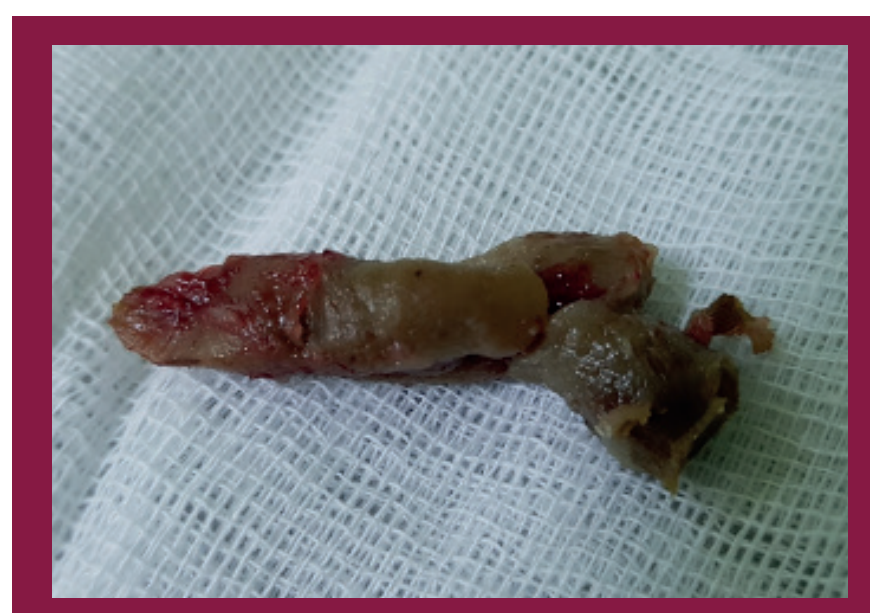

Figure 2. Hardened mucus plug in the lumen of the appendix 
An informed consent was obtained from the patient's parents for the publication of this case report containing photographs of the operation.

\section{Discussion}

Due to the increasing life expectancy, gastrointestinal problems have become a prominent element of morbidity in patients with CF. Although conditions such as gastroesophageal reflux and constipation are not specific to disease, they are common in patients with CF $(7,8)$. Some complications, such as DIOS, are specific to $\mathrm{CF}$ and require special knowledge during the diagnosis and treatment stages.

It is noteworthy that the incidence of acute appendicitis in patients with $\mathrm{CF}$ is low compared to the general population. The incidence of appendicitis was reported as $1 \%$ in a study including cases with CF (9). Similarly, McCarthy et al. (10) reported the incidence of appendicitis in cases with CF as 1-2\% compared to $7 \%$ of the general population. These authors attributed the low incidence of appendicitis in cases with CF to the absence of complete obstruction due to the consistently produced thick viscous mucus and the distention it provides. Probably, periodic regression of the complaints and physical examination findings in our case were related to the same reason. The mucus plug that fills the entire lumen and extends into the cecum has revealed this result due to partial obstruction. On the other hand, the same authors noted that the low incidence of appendicitis might also be due to prophylactic antibiotics used by patients with CF. Usage of antibiotics is able to hide the symptoms of acute appendicitis in these cases.

The defect in the release of chloride and water into the intestine, increased acidity in the lumen and loss of bile salts contribute to the development of DIOS (11). The lower right quadrant pain, nausea, vomiting, abdominal distention, failure to pass flatus or stool are the characteristic findings in these CF patients $(11,12)$. The abdominal X-ray is recommended in DIOS, but may fail to distinguish ileus from other abdominal pathologies seen in CF (13). Due to the proximity of anatomical regions and the similarity of their clinical presentations, appendicitis may mimic DIOS. The similar features of many abdominal pathologies such as DIOS, volvulus, intussusception, Crohn's disease, fibrosing colonopathy and colon carcinoma in CF increase the risk of misdiagnosis, especially in terms of appendicitis (6). Our patient applied with similar complaints and initial physical examination findings were not compatible with acute abdomen. There was significant constipation appearance in abdominal X-ray. The septic markers became negative during the follow-up period and this prolonged the accurate diagnosis process. Although there were no significant findings compatible with acute appendicitis in serial physical examinations, markers suggesting acute appendicitis in repeated ultrasound were effective in laparotomy decision. Computed tomography was not preferred due to intense radiation exposure in this case.

\section{Conclusion}

Although the incidence of appendicitis is low in patients with $\mathrm{CF}$, there is no easy way to make an accurate and rapid diagnosis. Ultrasound is a highly effective method in the diagnosis of appendicitis in younger children and can be easily repeated if necessary. Although DIOS is the most common cause of abdominal pain in the right iliac fossa in patients with CF, acute appendicitis should also be kept in mind. Pediatric CF patients with refractory or unexplained abdominal symptoms deserve proper follow-up, extensive research and a higher index of suspicion. With the help of diagnostic tools, surgical intervention is both diagnostic and therapeutic, especially in patients who do not improve clinically.

\section{Acknowledgements}

The author thanks Prof. Ayşenur Celayir for her support and scientific contributions.

\section{Ethics}

Informed Consent: Informed consent was obtained from the patient's parents for the publication of this case report containing photographs of the operation.

Peer-review: Externally peer-reviewed.

Financial Disclosure: The author declared that this study received no financial support.

\section{References}

1. Drumm ML, Collins FS. Molecular biology of cystic fibrosis. Mol Genet Med. 1993;3:33-68. [Crossref]

2. Rowe SM, Miller S, Sorscher EJ. Cystic fibrosis. N Engl J Med. 2005;352:19922001. [Crossref]

3. Ratjen F, Döring G. Cystic fibrosis. Lancet. 2003;361:681-689. [Crossref]

4. Ahmed N, Corey M, Forstner G, Zielenski J, Tsui LC, Ellis L, et al. Molecular consequences of cystic fibrosis transmembrane regulator (CFTR) gene mutations in the exocrine pancreas. Gut. 2003;52:1159-1164. [Crossref]

5. Nousia-Arvanitakis S. Cystic fibrosis and the pancreas: recent scientific advances.J Clin Gastroenterol. 1999;29:138-142. [Crossref]

6. Chen $\mathrm{CH}$, Chang CC, Yang BY, Lin PY,Wang CS. Acute appendicitis mimicking intestinal obstruction in a patient with cystic fibrosis.J Formos Med Assoc. 2012;111:580-583. [Crossref]

7. Sabati AA, Kempainen RR, Milla CE, Ireland M, Schwarzenberg SJ, Dunitz $\mathrm{JM}$, et al. Characteristics of gastroesophageal reflux in adults with cystic fibrosis.J Cyst Fibros. 2010;9:365-370. [Crossref]

8. van der Doef HP, Kokke FT, Beek FJ, Woestenenk JW, Froeling SP, Houwen $\mathrm{RH}$. Constipation in pediatric cystic fibrosis patients: an underestimated medical condition.J Cyst Fibros. 2010;9:59-63. [Crossref]

9. Shields MD, Levison H, Reisman JJ, Durie PR, Canny GJ.Appendicitis in cystic fibrosis. Arch Dis Child. 1991;66:307-310. [Crossref] 
10. McCarthy VP, Mischler EH, Hubbard VS, Chernick MS, di Sant'Agnese PA. Appendiceal abscess in cystic fibrosis. A diagnostic challenge. Gastroenterology. 1984;86:564-568. [Crossref]

11. Colombo C, Ellemunter H, Houwen R, Munck A, Taylor C, Wilschanski M, et al. Guidelines for the diagnosis and management of distal intestinal obstruction syndrome in cystic fibrosis patients. J Cyst Fibros. 2011;10 Suppl 2:S24-S28. [Crossref]
12. Dray X, Bienvenu T, Desmazes-Dufeu N, Dusser D, Marteau P, Hubert D. Distal intestinal obstruction syndrome in adults with cystic fibrosis. Clin Gastroenterol Hepatol. 2004;2:498-503. [Crossref]

13. Nassenstein K, Schwerger B, Kammer M, Status J, Lauenstein T, Barkhausen J. Distal intestinal obstruction syndrome in the early postoperative period after lung transplantation in a patient with cystic fibrosis: morphological findings on computed tomography. Gut. 2005;54:1662-1663. [Crossref] 